Types of Coproduction and Differential Effects on Organizational Performance: Evidence from the New York City School System

\author{
Julio César Zambrano-Gutiérrez \\ Amanda Rutherford \\ Sean Nicholson-Crotty \\ School of Public and Environmental Affairs \\ Indiana University Bloomington
}




\title{
Types of Coproduction and Differential Effects on Organizational Performance: Evidence from the New York City School System
}

\begin{abstract}
A growing body of literature explores the process of coproduction by citizens and government employees in providing goods and services, yet research that attempts to link coproduction to organizational performance offers contradictory findings. It is possible that these conflicting results are a consequence of trying to compare distinct categories of coproduction. This study identifies types of coproduction, classified by which organizational tasks citizens can influence during stages of policy design and implementation, and tests whether these types have different effects on student proficiency in Mathematics and English Language Arts using data from New York City schools between 2007 and 2009. This study then tests the degree to which different types of coproduction moderate the negative effect of environmental turbulence on performance. Results confirm that types of coproduction have varying effects on organizational performance and can reduce, and even eliminate, the negative effect of a turbulent environment on student outcomes.
\end{abstract}


Scholars increasingly study coproduction between citizens and government employees as a mechanism for improving organizational outcomes in the public sector. However, these studies have often produced contradictory findings regarding the effect of coproduction on organizational outcomes (Bovaird and Downe 2008, Yang and Pandey 2011, Vamstad 2012, Jakobsen 2013, Jakobsen and Andersen 2013, Bartenberger and Széscilo 2016). This study argues that these mixed findings may arise because existing studies have tried to compare distinct types of coproduction that can have different effects on organizational outcomes.

Indeed, previous research has identified numerous types of coproduction and offered taxonomies for classifying these types (see for example Arnstein 1969, Whitaker 1980, Brudney and England 1983, Linders 2012, Brandsen and Honingh 2015). Despite these attempts to distinguish types of coproduction, there has been very little research on the varying effects of these types on organizational outcomes. Moreover, the ambiguity in the definition of coproduction (Ewert and Evers 2014) has limited the capacity for generalizable conclusions.

In order to address this challenge, this study uses a recent typology to operationalize multiple types of coproduction and test for different effects on organizational outcomes. Specifically, we use the Brandsen and Honingh (2015) categories, which suggest that scholars must account for two dimensions of coproduction when interested in understanding linkages to organizational outcomes: 1) the extent to which citizens are involved in the implementation and design of a public service and 2) the influence of the tasks implemented by the citizens on organizational core services. In other words, the effect of coproduction on organizational outcomes is conditional on the level of access and influence users have in the provision of a public service, from its design to its implementation. 
This study also examines the degree to which different types of coproduction may alter the relationship between the environment and organizational performance. Research suggests that external factors and coproduction may have some joint effect on organizational performance (Fledderus, Brandsen, and Honingh 2015), and we further develop the argument that certain types of coproduction might moderate the effect of external factors on the outcomes produced by an organization. Both theoretically and practically, it is important to consider which types of coproduction are more effective in influencing organizational outcomes under different external environments.

Using data from New York City schools between 2007 and 2009, this study first tests whether the type of coproduction between teachers and parents influences student proficiency in Mathematics and English Language Arts and, second, whether coproduction is able to moderate the negative effect of turbulence in the organizational environment. Results confirm that different types of coproduction have varying effects on performance. Specifically, coproduction between teachers and parents has a positive effect on student proficiency when parent input influences the design of core educational process but matters less when parent activities focus only on complementary (i.e. more peripheral) educational tasks. We also find that the potential benefits of coproduction are significantly larger for schools operating in more turbulent (defined here as more violent) environments.

\section{The Genealogy of Coproduction}

The concept of coproduction is the result of much discussion about the role of citizens (users) in the production of public services. Parks et al. (1981), in synthesizing literature, define coproduction as the combined productive effort of regular and consumer producers in the provision of public services. Different authors have since refined the conceptualization of 
coproduction in public administration to distinguish it from other participatory concepts. The term "regular producer" changed to "professional" (Brudney and England 1983, Bovaird 2007) or "paid employee" (Brandsen and Honingh 2015) to differentiate the roles between individuals outside the organization (Ostrom 1996) from those inside the organization who receive monetary payment. Coproduction now typically refers to long-term relationships (e.g., multiple, repeated interactions) between agencies that produce public goods and citizens who are contributing to the production process (Bovaird 2007). Here, we define coproduction as an active long-term relation between public employees and users in the production of public services that users will either directly or indirectly consume.

Beyond variation in the definition of coproduction, many have become interested in determining whether coproduction has a meaningful effect on organizational outcomes. On one hand, some work finds evidence that coproduction improves the quality of public services (Vamstad 2012, Jakobsen and Andersen 2013), increases the credibility of and trust in government, facilitates administrative decision making and consensus building (Yang and Pandey 2011), and specializes service provision according to different user needs (Bovaird and Downe 2008). However, another set of studies suggests that coproduction can impede performance due to resistance from professional groups, particularly when the production of the service requires specialized skills (Bovaird and Downe 2008, Shim et al. 2010).

In the midst of these mixed findings, scholars have proposed that the effect of coproduction on performance is contingent on organizational characteristics. For example, coproduction can increase the level of uncertainty for employees who are in charge of key organizational processes (Fledderus, Brandsen, and Honingh 2015), not necessarily producing a win-win situation for both users and organizations (Bartenberger and Széscilo 2016), making 
coproduction somewhat undesirable. Thus, organizational structures and coproduction may have some combinative effect on organizational processes, decisions, and outcomes (King et al. 1998).

In an attempt to better describe and understand the effect of coproduction, scholars have proposed numerous typologies of user participation in the production of public services. Often these have created taxonomies based on the level of engagement of the citizenry (see for example Arnstein 1969, Whitaker 1980) and the level of analysis as individual, group, or collective (Brudney and England 1983). Previous work also identified multiple dimensions along which coproduction might occur, including provider versus beneficiary scales and stages of the service delivery lifecycle (Linders 2012).

Brandsen and Honingh (2015) provide arguably the most comprehensive typology for studying the effects of coproduction on organizational outcomes. Their schema accounts for two key dimensions: 1) the extent to which citizens are involved in the implementation and design of the public service and 2) the influence of the tasks implemented by the citizens in core organizational services. For example, the highest degree of coproduction is present when users are part of the implementation and design of a critical component in the production of the service. At the other end of the scale, the lowest level of coproduction occurs when users perform, but do not help to design, tasks that complement production but do not directly affect the core goals and processes. Compared to other discussions of coproduction types, the Brandsen and Honingh typology has the advantage of conditioning expected organizational outcomes on the level of access and influence users have in the provision of a public service, from design to implementation.

Despite the effort to develop a taxonomy of coproduction, little research has assessed the effect these different types have on organizational performance. As a result, disagreements about 
the effect of coproduction is likely a consequence of combining different levels of coproduction into a single measure. For instance, representative democracy is considered an example of coproduction (Aligica and Tarko 2013), as citizens provide information to government about their preferences in order to shape the production of public goods. However, overall satisfaction with government performance will differ between users who only cast a vote for a politician offering more resources to public safety compared to users who invest additional time in providing information to the government through, for example, 311-systems for improving public safety (Clark and Rokakis 2014). Understanding which outcomes are influenced by varying types of coproduction is important for designing structures that shape interactions among different institutional actors as well as planning to maximize the effectiveness of public services. Once the relationship between coproduction and organizational performance is properly identified via theory, practitioners can better determine which types of coproduction to pursue in the context of their specific environment.

\section{Expected Effects of Coproduction Types}

In creating a more refined typology of coproduction, Brandsen and Honingh (2015) encourage scholars to compare types of coproduction in order to better understand how coproduction is connected to individual or organizational outcomes in a way that better reflects real-world occurrences. Using this typology as a starting point, we argue that core organizational outcomes will vary more when users are active in the design and implementation of tasks related to organizational outcomes rather than those outside of the organizational core.

When considering involvement in service design, citizens can be (1) recipients of information, (2) constituents included in informational dialogue, or (3) key actors in strategic decision-making processes. Regarding service type, citizens can be (1) entirely outside of the 
organization, (2) part of decisions on the periphery of the organization, or (3) part of planning service provisions that define the core purpose of the organization.

Along either of the two dimensions, coproduction types should positively influence performance in a manner that grows in magnitude due to at least three phenomena - the level of buy-in, the effects of diversity in decision-making, and the generation of shared values. First, as coproduction becomes centered more closely around the core of the organization and involves clientele in forming strategies for delivering services, citizens should be more likely to invest in decision processes and have higher levels of buy-in when decisions are made (this is similar to discussions related to successful organizational change such as Fernandez and Rainey 2006). Second, greater interactions between professional bureaucrats and citizens in the decision making process should also allow for a higher level of diversity in the types of strategies proposed in the organization (e.g., Dutton and Duncan 1987, McLeod and Lobel 1992). With additional options on the table, individuals involved in the decision making process should have more perspectives by which to compare strategies to determine which route appears most useful for the organization. Finally, the more bureaucrats and citizens interact in meaningful decision making processes and the closer these decisions relate to the core of the organization, the more likely that such interactions will produce shared values and priorities among multiple groups involved in the process of service production (Stoker 2006). This may occur in part from shared socialization experiences as well as the dissolution of previously held perceptions and stereotypes.

Some examples in public administration research illustrate that increasing levels of user involvement in service implementation, particularly with core services, will have a larger positive effect on organizational performance than user involvement in complementary tasks. For 
example, in the context of childcare service provision in Sweden, Vamstad (2012) finds that parents involved in the implementation of core tasks in childcare centers are more satisfied with the quality of the service than parents participating in complementary services (i.e., cleaning and repairs). Similarly, Gill et al. (2014) argue that citizen collaboration with police in neighborhood problem solving efforts has a larger effect on citizen satisfaction, perceptions of disorder, and perceptions of police legitimacy than do efforts that only provide information to or solicit feedback from citizens. Following the notion that coproduction should have a positive effect on organizational performance, the first hypothesis in this study can be articulated as:

Hypothesis 1: Coproduction in which users play an active role in the design of core services in an organization will improve organizational performance more than coproduction in which users do not play an active role in the design of core services. It is also possible that the effect of organizational factors, particularly those that negatively influence performance, may be moderated by specific types of coproduction. Here, we focus on the negative influence of organizational turbulence, which generally refers to externally provoked changes that increase uncertainty in organizations. Turbulent environments are generally expected to lower organizational performance because managers in uncertain environments spend much of their time responding to unexpected events and crises rather than acting strategically to improve organizational performance (O'Toole and Meier 2015). In other words, they are reactive instead of proactive. Uncertainty, however, can be reduced when the organization gathers information about its clientele and works to improve the capacity of users to assist in the production of public services. The impact of such efforts on organizational performance should be particularly high when the organization works to reduce uncertainty surrounding inputs that are vital to core services and tasks. If we expect performance to be low as 
a result of turbulence, it is also likely that these organizations have more room to improve (e.g., is it easier to go from 20 percent to 40 percent of production expectations than from 90 percent to 95 percent).

A field experiment in childcare facilities in Denmark has provided some support for the idea that coproduction can reduce input uncertainty and improve organizational outcomes. Immigrant parents, who often have limited Danish language skills (input uncertainty), received specialized material (e.g., children's books, games, tutorial DVD about language development techniques) for aiding in the language development of their preschool children. Results indicate that the benefits of coproduction were greatest for these children, suggesting organizations that proactively reduce input uncertainty through coproduction, rather than simply reacting to the inputs that flow from the environment, achieve higher performance (Jakobsen 2013, Jakobsen and Andersen 2013). Thus, the second main hypothesis can be illustrated in two parts:

Hypothesis 2a: Coproduction moderates the negative effect of environmental turbulence on organizational performance.

Hypothesis 2b: Coproduction in which users play an active role in the design of core services in an organization offsets the negative effect of environmental turbulence on organizational performance more than coproduction in which users do not play an active role in the design of core services.

\section{Coproduction in K-12 Education}

Education is an ideal policy area in which to study coproduction because it involves several stakeholder groups that each contribute significantly to the learning processes of students. While knowledge gained about coproduction in education may not be generalizable to 
all other contexts, it provides an area in which multiple types of coproduction can be identified for analysis.

Understanding the effect of activities coproduced between parents and teachers on student achievement has been popular among scholars of education (see a synthesis in Henderson and Mapp 2002). A high level of parent participation in education is generally shown to correlate positively with student achievement (Henderson 1987, Astone and McLanahan 1991, Haveman and Wolfe 1995, Schneider et al. 2000, Henderson and Mapp 2002, Bryk et al. 2010). While researchers have not used a standard definition of parental involvement to allow for a more direct comparison of their findings, the evidence suggests that the magnitude of effects can vary dramatically (Epstein 1995, Singh et al. 1995, Epstein and Sanders 2000, Fan and Chen 2001, Katyal and Evers 2007). This type of variation points to the potential for differentiating among types of parental involvement specifically and coproduction more generally.

\section{Data}

Data for this study come from New York City Department of Education (NYCDE) surveys administered yearly to 1.8 million parents, teachers, and students between 2007 and 2009. This study does not include surveys collected after 2009 due to changes in the methodology used to determine student proficiency. Before 2010, a student could be categorized as academically proficient in Mathematics and English Language Arts after reaching 650 points in the New York State Department of Education standardized tests. After 2010, the format for the standardized tests changed, and the cut score varied by subject and grade (NYCDE 2010). For the 1,021 NYC schools in this data, the response rate across all three years (2007-2009) was $64 \%$ for the teacher survey. The surveys were an essential component of the Children First accountability initiative to assess the learning environment at each school and particularly to 
promote parent involvement in the provision of educational services. As Joel I. Klein, Chancellor of the NYCDE from 2002-2010, noted, "When one parent speaks, schools listen; when one million parents speak, schools change" (Loeser et al. 2007). Additional information for measuring organizational traits and performance was obtained from the New York State Education Department (NYSED).

The analysis below includes only traditional schools where at least eight teachers and eight parents answered surveys (traditional schools do not include special education schools, alternative schools, charter schools, early childhood schools, transfer schools, and Young Adult Borough Centers). The dataset also does not contain observations with missing values or inconsistencies (i.e. percentages greater than 100\%), which represented approximately three percent of the observations from the total sample. The exclusion of these cases (models not shown) did not change the main results of our study; standard errors increased but did not affect the statistical significance of coefficients of interest. The final database is an unbalanced panel with 2,849 school-year observations. Descriptive statistics for the variables used in this study are summarized in Table 1.

\section{$<<<$ Table 1 about Here $>>>$}

\section{Dependent Variable}

Because standardized test scores are the dominant metric by which schools are held accountable in the era of No Child Left Behind, we use them to measure performance. More

specifically, we measure organizational performance using results from state standardized exams for 3rd-8th grade in English Language Arts (ELA) and Mathematics and the pass rates from Language and Mathematics exams required to graduate from high school. Our performance measure combines the percent of students between 3rd-8th grade who score above the state's 
predefined cut score in ELA and Mathematics, and the percent of 9th-12th grade students who pass Mathematics and ELA exams required to graduate high school. This performance measure is the average of the ELA and Mathematics pass rates, expressed as percentages.

\section{Independent Variables}

Using the Brandsen and Honingh (2015) typology as a theoretical guide, this study derives two measures of coproduction, which we term Design-Core and ImplementComplement, between parents and teachers from questions in the NYCDE teacher survey. We expect Design-Core coproduction to directly influence the design of educational services and, thus, to have a positive effect on student achievement that is higher in magnitude than Implement-Complement coproduction. As defined below, each measure is produced through factor analysis. Factor analysis has the advantage of representing unobservable variables (latent variables) using a linear combination of observable variables to estimate our measures. For questions mentioned below, the NYCDE uses 4-point Likert scales to capture teacher responses to the questions used in our measures and scores each response category in the following manner: 10 points for strongly agree, 6.7 for agree, 3.3 for disagree, and 0 for strongly disagree. To construct the Design-Core index, we create a factor variable using teacher responses to two survey questions asking how much teachers agree or disagree with statements about their experiences with parents. These include perceptions of whether a school prioritizes obtaining information from parents and perceptions of whether a school uses parent feedback to improve instructional practices and meet student learning needs. Exact question wording and factor analysis details are available in Table 2 below. The index has an eigenvalue of 1.96 and accounts for $98 \%$ of the variance for the selected teacher survey items. We argue that responses to these 
questions indicate the level of access parents have to design core organizational needs and priorities which, in the context of school, is primarily teaching in the classroom.

$<<<$ Table 2 about here $>>>$

Second, the Implement-Complement coproduction index is based on three questions concerning teachers' perceptions about communication with parents regarding student performance, learning expectations, and options for extra educational services (e.g., tutoring, after-school programs, workshops). These questions and the factor loading are shown in Table 3. The index has an eigenvalue of 1.94 , accounting for the $65 \%$ of the variance for the selected teacher survey items. We argue this measure captures coproduction that does not influence the design of core services but still communicates information between school employees and parents. In other words, schools share information with parents to promote their participation in complementary educational tasks.

\section{$<<<$ Table 3 about Here $>>>$}

While the Brandsen and Honingh (2015) typology is used as a guide for operationalizing different types of coproduction, our two indices are admittedly imperfect measures given the information available in these surveys. In other words, we are limited by the fact that we are using secondary data that were not designed with the sole intent of studying coproduction. Yet, there are many strengths to using this type of large and extensive dataset, and our two measures of coproduction allow us to tease out differences in the type of involvement parents have in local schools.

We are also interested in gauging whether coproduction moderates the effect of turbulence on organizational performance. In this study, we measure turbulence in schools as the level of violence present in schools. The unpredictability of violent acts increases the level of 
uncertainty in schools and can reduce organizational performance, including student achievement (Andrews 2009). As a result, we argue more managerial effort such as coproduction is needed to minimize the negative effect of turbulence on student performance. The NYSED calculates a School Violence Index (SVI) to categorize persistently dangerous schools and to implement strategies to ensure a safe environment for students. The SVI represents a weighted sum of different violent incidents. For example, a homicide receives a weight of 100 points, robbery 40 , and weapon possession 15 . The number of violent incidents is multiplied by their respective weight, added together, and divided by the student enrollment in each school. The models in this study include a logged measure of this index to adjust for a skewed distribution. Models in the analysis below also include interactions between the logged violence index and each measure of coproduction. These interaction terms test the second hypothesis of this studythat the negative effect of environmental turbulence on student proficiency will be smaller when the level of coproduction is high.

\section{Control Variables}

The analysis below includes several school characteristics to properly control for other factors that influence student performance. Using public records from the NYCDE, this analysis includes demographic characteristics of students - the percent of students who are female, black, Hispanic, Limited English Proficiency (LEP), or live below the poverty line - that may help to explain variation in student achievement on standardized tests. For example, public schools with a high percentage of students living in poverty and a large share of LEP students are expected to have a lower percentage of proficient students than other schools.

Next, we use public records from the NYCDE to control for the level of resources available within schools, as resources are often correlated with student performance. The logged 
measure of classroom instructional expenses per student includes personnel expenses (e.g., teachers, paraprofessionals), supplies (e.g., books, equipment), training (e.g., professional development), and services (e.g., contracted instructional services, summer and evening school). Logged parent involvement activity resources were obtained from this data source as a subcategory of instructional support services.

This study also controls for administrative intensity, as this may indicate some level of personnel resources. Using data from the NYSED, we calculate the ratio of administrative personnel to teachers. Administrative personnel is defined as the number of principals, assistant principals, and other professional staff working at each school. It should be noted that one-third of the cases in our sample reported no administrative personnel; we viewed these cases as data errors (schools need administrators to function even minimally) and replace these values with data reported in the prior period. As a robustness check, we ran all models (1) excluding these observations and (2) excluding the variables from the models. The results (not shown here) did not alter the main findings presented in the analysis below. As such, we use the replaced values so as not to lose a large number of observations in our sample.

Finally, NYSED records were used to control for teacher characteristics-yearly teacher turnover rate, the share of teachers with less than three years of experience, and the share of core classes led by teachers who do not meet all state qualification standards. Teachers in New York are classified as meeting qualification standards if they possess a bachelor's degree, are state certified or licensed, and prove that they have mastered the subject they teach through Content Specialty Tests (CSTs) (NYSED 2015, NYSTCE 2016). A measure of standardized class size was also included in all models. Following Favero, O’Toole and Meier (2016), class size is a standardized measure calculated as the combination of different class sizes for different grade 
levels. Smaller class sizes should have a positive effect on student achievement (Angrist and Lavy 1999).

\section{Findings}

All models below use fixed effects regression to capture within-school changes and include year fixed effects to consider over-time trends that can affect cross-sectional time-series data. Standard errors are clustered by school to account for any correlation between observations in the same school over time.

The results from baseline models are presented in Table 4. Models 1 and 2 report the findings from models focused on Design-Core coproduction and Implement-Complement coproduction separately while Model 3 includes both types of coproduction. Model 1 illustrates that Design-Core coproduction can have a substantive influence on student performance. For each one-unit increase in this coproduction measure, the average passage rate for students on standardized exams increases by 1.13 percentage points. Across the range of this coproduction variable, the change could be as large as 6.78 percentage points, which is quite notable for passage rates on these exams. The results presented in Model 2 suggest that the implementcomplement coproduction variable has no significant relationship with student performance. While this supports the assumption that complimentary coproduction will be less meaningful than Design-Core coproduction for improving organizational performance, it is contrary to expectations in that it does not appear to have any relationship with performance.

$$
<<<\text { Table } 4 \text { about Here }>>>
$$

When both variables are included in Model 3, similar results are produced. The coefficient for Design-Core coproduction grows such that a one-unit increase in coproduction increases student performance by 1.25 percentage points. Coproduction via Design-Core 
coproduction is clearly an important strategy for boosting student outcomes (at least as measured by performance on standardized tests). The coefficient for Implement-Complement coproduction actually becomes negative but remains indistinguishable from zero statistically. This informational exchange type of coproduction does not appear to have a direct effect on student outcomes. Of course, this null finding does not mean that these efforts are meaningless; such efforts may have effects on important educational processes and, as we have hypothesized, an indirect influence on performance.

Though not the focus of this study, administrative intensity, resources for instructional support, and the share of Hispanic students consistently have a positive correlation with student performance across all three models. The share of classes taught by unqualified teachers, teacher turnover, and the share of teachers with fewer than three years of experience are negatively associated with student performance. These variables certainly stress the importance of teachers for student performance. Interestingly, the results across all models in Table 4 show that the negative linkage between school violence and student performance is not statistically significant (though p-values just miss the mark, ranging from .12 to .15). At first sight, this does not provide strong support for the notion that turbulent contexts have a negative effect on organizational performance.

In order to examine whether coproduction moderates any negative linkages that exist between turbulent environments and organizational performance, interactions between each coproduction measure and the violence index were added to the baseline models. Table 5 reports three columns representing models that include each interaction term separately (Models 1 and 2) and then together (Model 3). All specifications support the hypothesis that coproduction moderates the effect of turbulence on organizational performance. In fact, both types of 
coproduction are meaningful in mitigating the effect of turbulence. It is also worth mentioning that neither coproduction measure is a function of school violence. Granger tests fail to reject the null hypotheses of no relationship at $\mathrm{p}=.05$ between each of the coproduction measures and the level of school violence.

The size of the interaction terms suggests that the moderating effect of coproduction may vary, and this difference is easier to interpret graphically. Because findings in Models 1 and 2 are similar to Model 3, we focus on marginal effects plots for Model 3. Figure 1 shows the marginal effect of violence on student performance as the level of Implement-Complement and DesignCore coproduction shift, respectively. While Implement-Complement coproduction did not have a significant direct effect on student performance in Table 4, the interactive model shows that it moderates the relationship between violence and student proficiency. In fact, ImplementComplement coproduction almost appears to change the sign of the marginal effect of violence for extreme values of coproduction (though only two observations are in that range of the data with values of implement-compliment coproduction at 3.97 and 3.68). Similar to ImplementComplement coproduction, Design-Core coproduction also minimizes the negative effect of violence. Only in cases where coproduction is low is the marginal effect of violence negative, showing again the extent to which this type of coproduction not only improves organizational performance directly, but also buffers the organization from negative environmental conditions. In sum, when parents are an integral part of the school community, either through complementary or core efforts, negative environments surrounding the school have no effect on student learning at all.

$<<<$ Table 5 about here $>>>$

$<<<$ Figure 1 about here $>>>$ 


\section{Conclusion}

This study contributes to the theoretical understanding of coproduction and its relationship to organizational performance in the public sector. The results suggest that contradictory findings regarding the effects of coproduction on organizational outcomes arise in part from the failure to distinguish among specific categories of coproduction. By defining and testing different types of coproduction on the same organizational outcome, the findings reveal that not all types of coproduction have a direct effect on organizational outcomes. Particularly, some organizational outcomes may only respond directly to coproduction when the interactions between users and employees influence core organizational tasks via the design of public services.

This study also contributes to the existing literature by demonstrating that different types of coproduction can moderate the effect of the turbulent environments on organizational performance. As a result, organizations immersed in turbulent environments should opt for setting up coproductive systems where users have the ability to design and implement core organizational tasks. This is because as the level of turbulence increases, organizations cannot predict the external events that might have negative effects on organizational outcomes. Thus, the types of coproduction that provide more access to citizens for collaborating in core tasks can potentially uncover shared values and priorities among public employees and users, reducing the uncertainty from the external environment and moderating the negative effect of turbulence on organizational outcomes. This result suggests that types of coproduction that do not directly affect organizational performance are still important because they serve other roles or have an indirect influence on organizational performance. 
While this study focuses on the context of education policy and may not be generalizable to all policy contexts, it offers a set of hypotheses that can be tested in other organizational settings to further refine knowledge of how coproduction is linked with performance outcomes. An additional potential limitation of the study is the short time frame (three years) in which the data allow us to observe the effect of coproduction. When possible, future studies should evaluate the effects of different types of coproduction over longer periods of time. It is also worth mentioning that, while we are focused on coproduction and the importance of parents as stakeholders, schools and school systems can also be influenced by other environmental factors including shifts in political power at the local, state, and federal levels; changes in policies related to charter schools or vouchers; and the general economic state of the local community. For example, the United States was experiencing an economic downturn during the time period in which our data were collected. Other periods of time (e.g., economic booms) or other locations may find slightly different linkages between coproduction and organizational performance, which underscores the benefit of replication studies. Future work examining coproduction that involves local non-profit or for-profit organizations may also be of interest to many scholars.

The main findings of this study are an initial step in determining the type of coproduction that may be required for shifting organizational outcomes embedded in different types of external environments. This is important since policymakers and practitioners who wish to design coproductive efforts that effectively bolster the performance of their organizations should take into consideration not only the type of organizational outcome that they want to improve but also which type of coproductive effort is more effective to deal with their external environment. 


\section{Acknowledgement}

We thank Nathan Favero for sharing the data for this study and the reviewers for their valuable comments on earlier versions of the paper. 


\section{References}

Aligica, P.D. and V. Tarko. 2013. 'Co-Production, Polycentricity, and Value Heterogeneity: The Ostroms' Public Choice Institutionalism Revisited', American Political Science Review, 107, 726-741.

Andrews, R. 2009. 'Organizational Task Environments and Performance: An Empirical Analysis', International Public Management Journal, 12, 1-23.

Angrist, J.D. and V. Lavy. 1999. 'Using Maimonides' rule to estimate the effect of class size on scholastic achievement', The Quarterly Journal of Economics, 114, 2, 533-575.

Arnstein, S.R. 1969. 'Ladder of Citizen Participation', Journal of the American Institute of Planners, 35, 216-224.

Astone, N.M. and S.S. McLanahan. 1991. 'Family Structure, Parental Practices and High School Completion', American Sociological Review, 56, 309-320.

Bartenberger, M. and D. Széscilo. 2016. 'The Benefits and Risks of Experimental Coproduction: The Case of Urban Redesign in Vienna', Public Administration, 94, 509-525.

Bovaird, T. 2007. 'Beyond Engagement and Participation: User and Community Coproduction of Public Services', Public Administration Review, 67, 846-860.

Bovaird, T. and J. Downe. 2008. 'Innovation in Public Engagement and Co-production of Services', Policy Paper for Department of Communities and Local Government, 39.

Brandsen, T. and M. Honingh. 2015. 'Distinguishing Different Types of Coproduction: A Conceptual Analysis Based on the Classical Definitions', Public Administration Review, 76, 427-435.

Brudney, J.L. and R.E. England. 1983. 'Toward a Definition of the Coproduction Concept', Public Administration Review, 43, 59-65.

Bryk, A.S., P.B. Sebring, E. Allensworth, J.Q. Easton and S. Luppescu. 2010. Organizing schools for improvement: Lessons from Chicago. University of Chicago Press.

Clark, B.Y. and M. Rokakis. 2014. 'Do 311 Systems Shape Citizen Satisfaction with Local Government?',Available at SSRN: https://ssrn.com/abstract=2491034.

Dutton, J.E. and R.B. Duncan. 1987. 'The Influence of the Strategic Planning Process on Strategic Change', Strategic Management Journal, 8, 103-116.

Epstein, J.L. 1995. 'School/Family/Community Partnerships: Caring for the Children We Share', The Phi Delta Kappan, 76, 701-712.

Epstein, J.L. and M.G. Sanders. 2000. 'Connecting Home, School, and Community', in M.T. Hallinan (ed), Handbook of the Sociology of Education. Boston, MA: Springer US, pp. 285-306.

Ewert, B. and A. Evers. 2014. 'An Ambiguous Concept: On the Meanings of Co-production for Health Care Users and User Organizations?', Voluntas: International Journal of Voluntary \& Nonprofit Organizations, 25, 425-442.

Fan, X. and M. Chen. 2001. 'Parental Involvement and Students' Academic Achievement: A Meta-Analysis', Educational Psychology Review, 13, 1-22.

Favero, N., K.J. Meier and L.J. O'Toole. 2016. 'Goals, Trust, Participation, and Feedback: Linking Internal Management with Performance Outcomes', Journal of Public Administration Research and Theory, 26, 2, 327-343.

Fernandez, S. and H.G. Rainey. 2006. 'Managing Successful Organizational Change in the Public Sector', Public Administration Review, 66, 168-176. 
Fledderus, J., T. Brandsen and M.E. Honingh. 2015. 'User Co-production of Public Service Delivery: An Uncertainty Approach', Public Policy and Administration, 30, 145-164.

Haveman, R. and B. Wolfe. 1995. 'The Determinants of Children's Attainments: A Review of Methods and Findings', Journal of Economic Literature, 33, 1829-1878.

Henderson, A.T. 1987. The Evidence Continues to Grow: Parent Involvement Improves Student Achievement. An Annotated Bibliography. National Committee for Citizens in Education Special Report. ERIC.

Henderson, A.T. and K.L. Mapp. 2002. A New Wave of Evidence: The Impact of School, Family, and Community Connections on Student Achievement. Annual Synthesis 2002., National Center for Family and Community Connections with Schools. ERIC.

Jakobsen, M. 2013. 'Can Government Initiatives Increase Citizen Coproduction? Results of a Randomized Field Experiment', Journal of Public Administration Research and Theory, 23, 27-54.

Jakobsen, M. and S.C. Andersen. 2013. 'Coproduction and Equity in Public Service Delivery', Public Administration Review, 73, 704-713.

Katyal, K.R. and C.W. Evers. 2007. 'Parents-Partners or Clients? A Reconceptualization of Home-School Interactions', Teaching Education, 18, 61-76.

King, C.S., K.M. Feltey and S. Bridget O'Neill. 1998. 'The Question of Participation: Toward Authentic Public Participation in Public Administration', Public Administration Review, 58, 317-326.

Linders, D. 2012. 'From E-government to We-government: Defining a Typology for Citizen Coproduction in the Age of Social Media', Government Information Quarterly, 29, 446454.

Loeser, S., D. Walker, D. Cantor and A. Jacob. 2007. Mayor Bloomberg And Chancellor Klein Unveil First-ever Citywide Survey To Learn About Public Schools. Office of the Mayor. City of New York.

McLeod, P.L. and S.A. Lobel. 1992. 'The Effects of Ethnic Diversity on Idea Generation in Small Groups', Academy of Management Proceedings: Academy of Management, pp. 227-231.

NYCDE (New York City Department of Education). 2010. NYC 2010 Mathematics and English Language Arts Citywide Test Results Grades 3 - 8. Performance \& Accountability.

NYCDE (New York City Department of Education). 2011. Performance \& Accountability. Available at: http://schools.nyc.gov/Accountability/default.html.

NYCDE (New York City Department of Education). 2017. School-Based Expenditure Reports. Offices \& Programs.

NYSED (New York State Education Department). 2011. Violent and Disruptive Incidents. School Safety \& Accountability. Available at: http://www.p12.nysed.gov/irs/vadir/vadiraccountability.html

NYSED (New York State Education Department). 2015. Equitable Distribution of Highly Qualified and Effective Teaching. New York: Office of Accountability.

NYSTCE (New York State Teacher Cerfitication Examinations). 2016. Tests for Teacher Certification.

New York State Testing and Accountability Reporting Tool. 2011. New York State Report Cards. Available at: https://www.nystart.gov/publicweb/ 
O’Toole, L.J. and K.J. Meier. 2015. 'Public Management, Context, and Performance: In Quest of a More General Theory', Journal of Public Administration Research and Theory, 25, 237-256.

Ostrom, E. 1996. 'Crossing the Great Divide: Coproduction, Synergy, and Development', World Development, 24, 1073-1087.

Parks, R.B., P.C. Baker, L. Kiser, R. Oakerson, E. Ostrom, V. Ostrom, S.L. Percy, M.B. Vandivort, G.P. Whitaker and R. Wilson. 1981. 'Consumers as Coproducers of Public Services: Some Economic and Institutional Considerations', Policy Studies Journal, 9, 1001-1011.

Schneider, M., P. Teske and M. Marschall. 2000. Choosing Schools: Consumer Choice and the Quality of American Schools. Princeton University Press.

Shim, J.T., T.S. Sheu, H.G Chen, J.J. Jiang, and G. Klein. 2010. 'Coproduction in successful software development projects', Information and Software Technology, 52, 10, 10621068.

Singh, K., P.G. Bickley, P. Trivette and T.Z. Keith. 1995. 'The Effects of Four Components of Parental Involvement on Eighth-Grade Student Achievement: Structural Analysis of NELS-88 data', School psychology review.

Stoker, G. 2006. 'Public Value Management: A New Narrative for Networked Governance?', The American Review of Public Administration, 36, 41-57.

Vamstad, J. 2012. 'Co-production and Service Quality: The Case of Cooperative Childcare in Sweden', Voluntas: International Journal of Voluntary and Nonprofit Organizations, 23, 1173-1188.

Whitaker, G.P. 1980. 'Coproduction: Citizen Participation in Service Delivery', Public Administration Review, 40, 240-246.

Yang, K. and S.K. Pandey. 2011. 'Further Dissecting the Black Box of Citizen Participation: When Does Citizen Involvement Lead to Good Outcomes?', Public Administration Review, 71, 880-892. 
TABLE 1. Descriptive Statistics

\begin{tabular}{lcccc}
\hline \multicolumn{1}{c}{ Variables } & Mean & S.D. & Min & Max \\
\hline Average pass rate $(\%)$ & 69.34 & 17.61 & 0.00 & 100.00 \\
Design-Core coproduction & 0.00 & 1.00 & -3.34 & 2.70 \\
Implement-Complement coproduction & 0.00 & 1.00 & -3.29 & 3.97 \\
School Violence Index (logged) & 0.29 & 0.25 & 0.00 & 1.97 \\
Administrative Personnel per Teacher & 0.00 & 1.00 & -2.41 & 6.21 \\
Per Capita Parents Involvement Expenses (logged) & 4.91 & 0.51 & 1.65 & 6.74 \\
Per Capita Classroom Instruction Expenses (logged) & 9.09 & 0.19 & 8.58 & 10.16 \\
Female students (\%) & 49.20 & 4.61 & 1.00 & 100.00 \\
Black students (\%) & 33.08 & 29.49 & 0.00 & 97.00 \\
Hispanic students $(\%)$ & 39.97 & 26.32 & 1.00 & 100.00 \\
Class size index & -0.04 & 0.97 & -4.25 & 4.38 \\
Core classes taught by unqualified teachers (\%) & 9.03 & 8.51 & 0.00 & 56.00 \\
Turnover rate of all teachers & 16.57 & 9.48 & 0.00 & 76.00 \\
Teachers with less than three years of experience $(\%)$ & 16.17 & 11.73 & 0.00 & 83.00 \\
Limited English Proficient students (\%) & 14.57 & 12.48 & 0.00 & 94.00 \\
Students in Poverty (\%) & 68.78 & 22.06 & 1.60 & 100.00 \\
\hline & & & & \\
\hline
\end{tabular}


TABLE 2. Design-Core Coproduction Factor Analysis

\begin{tabular}{|c|c|c|c|}
\hline Survey Item & $\begin{array}{c}\text { Factor } \\
\text { Loading }\end{array}$ & Uniqueness & $\begin{array}{c}\text { Scoring } \\
\text { coefficients }\end{array}$ \\
\hline \multicolumn{4}{|l|}{$\begin{array}{l}\text { Based on your experiences during the current } \\
\text { school year, how much do you agree or disagree } \\
\text { with the following statements? }\end{array}$} \\
\hline $\begin{array}{l}\text { Obtaining information from parents about student } \\
\text { learning needs is a priority at my school. }\end{array}$ & 0.99 & 0.02 & 0.51 \\
\hline $\begin{array}{l}\text { Teachers and administrators in my school use } \\
\text { information from parents to improve instructional } \\
\text { practices and meet student learning needs. }\end{array}$ & 0.99 & 0.02 & 0.51 \\
\hline Eigenvalue & 1.96 & & \\
\hline Proportion & 0.98 & & \\
\hline $\mathrm{N}$ & 2852 & & \\
\hline
\end{tabular}


TABLE 3. Implement-Complement Coproduction Factor Analysis

\begin{tabular}{|c|c|c|c|}
\hline \multicolumn{1}{|c|}{ Survey Item } & $\begin{array}{c}\text { Factor } \\
\text { Loading }\end{array}$ & Uniqueness & $\begin{array}{c}\text { Scoring } \\
\text { coefficients }\end{array}$ \\
\hline $\begin{array}{l}\text { How often during this school year have you: } \\
\text { Communicated with parents about their children's } \\
\text { progress in class? }\end{array}$ & 0.72 & 0.48 & 0.37 \\
$\begin{array}{l}\text { Sent parents written information on what you are } \\
\text { teaching and what students are expected to learn? }\end{array}$ & 0.86 & 0.27 & 0.44 \\
$\begin{array}{c}\text { Sent home information on services to help students or } \\
\text { parents such as: tutoring, after-school programs, or } \\
\text { workshops adults can attend to help their children in } \\
\text { school? }\end{array}$ & 0.83 & 0.32 & 0.43 \\
\hline Eigenvalue & 1.94 & & \\
\hline Proportion & 0.65 & & \\
\hline N & 2852 & & \\
\hline
\end{tabular}


TABLE 4. The Effect of Coproduction on Average Student Pass Rate

\begin{tabular}{|c|c|c|c|}
\hline & Model 1 & Model 2 & Model 3 \\
\hline Design-Core Coproduction & $\begin{array}{l}1.1260^{* * * *} \\
(0.2138)\end{array}$ & & $\begin{array}{l}1.2489^{* * *} \\
(0.2370)\end{array}$ \\
\hline Implement-Complement Coproduction & & $\begin{array}{c}0.0926 \\
(0.1888)\end{array}$ & $\begin{array}{l}-0.2705 \\
(0.2066)\end{array}$ \\
\hline School Violence Index (logged) & $\begin{array}{l}-1.2798 \\
(0.8970)\end{array}$ & $\begin{array}{l}-1.4019 \\
(0.9100)\end{array}$ & $\begin{array}{l}-1.2959 \\
(0.8986)\end{array}$ \\
\hline Administrative Personnel per Teacher & $\begin{array}{l}1.2504^{* * * *} \\
(0.2952)\end{array}$ & $\begin{array}{l}1.2716^{* * *} \\
(0.3005)\end{array}$ & $\begin{array}{c}1.2347^{* * * *} \\
(0.2946)\end{array}$ \\
\hline Per Capita Parents Involvement Expenses (logged) & $\begin{array}{c}2.1174^{* * * *} \\
(0.6013)\end{array}$ & $\begin{array}{c}2.0457^{* * * *} \\
(0.6186)\end{array}$ & $\begin{array}{c}2.1063^{* * * *} \\
(0.6003)\end{array}$ \\
\hline Per Capita Classroom Instruction Expenses (logged) & $\begin{array}{c}3.1663 \\
(2.6618)\end{array}$ & $\begin{array}{c}3.8127 \\
(2.6840)\end{array}$ & $\begin{array}{c}3.1847 \\
(2.6613)\end{array}$ \\
\hline Female students $(\%)$ & $\begin{array}{c}0.0997 \\
(0.0902)\end{array}$ & $\begin{array}{c}0.1074 \\
(0.0922)\end{array}$ & $\begin{array}{c}0.1036 \\
(0.0909)\end{array}$ \\
\hline Black students (\%) & $\begin{array}{c}0.0734 \\
(0.1044)\end{array}$ & $\begin{array}{c}0.0736 \\
(0.1067)\end{array}$ & $\begin{array}{c}0.0798 \\
(0.1041)\end{array}$ \\
\hline Hispanic students (\%) & $\begin{array}{c}0.1511^{*} \\
(0.0880)\end{array}$ & $\begin{array}{l}0.1501^{*} \\
(0.0889)\end{array}$ & $\begin{array}{c}0.1547^{*} \\
(0.0880)\end{array}$ \\
\hline Class size index & $\begin{array}{l}-0.2304 \\
(0.2444)\end{array}$ & $\begin{array}{l}-0.2620 \\
(0.2443)\end{array}$ & $\begin{array}{c}-0.2309 \\
(0.2440)\end{array}$ \\
\hline Core classes taught by unqualified teachers (\%) & $\begin{array}{c}-0.0427^{* *} \\
(0.0180)\end{array}$ & $\begin{array}{c}-0.0432^{* *} \\
(0.0179)\end{array}$ & $\begin{array}{c}-0.0414^{* *} \\
(0.0180)\end{array}$ \\
\hline Turnover rate of all teachers & $\begin{array}{c}-0.0803^{\text {**** }} \\
(0.0189)\end{array}$ & $\begin{array}{c}-0.0791^{* * *} \\
(0.0190)\end{array}$ & $\begin{array}{c}-0.0798^{* * * *} \\
(0.0188)\end{array}$ \\
\hline Teachers with less than three years of experience (\%) & $\begin{array}{c}-0.0777^{* * *} \\
(0.0251)\end{array}$ & $\begin{array}{c}-0.0738^{* * *} \\
(0.0257)\end{array}$ & $\begin{array}{c}-0.0770^{* * * *} \\
(0.0250)\end{array}$ \\
\hline Limited English Proficient students (\%) & $\begin{array}{c}0.1049 \\
(0.0782)\end{array}$ & $\begin{array}{c}0.0977 \\
(0.0797)\end{array}$ & $\begin{array}{c}0.1057 \\
(0.0782)\end{array}$ \\
\hline Students in Poverty $(\%)$ & $\begin{array}{c}0.0434 \\
(0.0290)\end{array}$ & $\begin{array}{c}0.0480 \\
(0.0296)\end{array}$ & $\begin{array}{c}0.0419 \\
(0.0291)\end{array}$ \\
\hline
\end{tabular}




\begin{tabular}{lccc} 
Constant & 9.1552 & 2.4347 & 8.4683 \\
& $(23.6206)$ & $(23.7925)$ & $(23.6567)$ \\
\hline School fixed-effects & Yes & Yes & Yes \\
Year fixed-effects & Yes & Yes & Yes \\
Observations & 2849 & 2849 & 2849 \\
Schools & 1021 & 1021 & 1021 \\
$\mathrm{R}^{2}:$ within & 0.7460 & 0.7421 & 0.7463 \\
\hline
\end{tabular}

Cluster Robust Standard Errors in parentheses: ${ }^{*} p<0.1,{ }^{* *} p<0.05,{ }^{* * *} p<0.01$ 
TABLE 5. The Effect of Coproduction and Turbulence on Average Student Pass Rate

\begin{tabular}{|c|c|c|c|}
\hline & Model 1 & Model 2 & Model 3 \\
\hline Design-Core Coproduction & $\begin{array}{c}0.3164 \\
(0.3056)\end{array}$ & $\begin{array}{l}1.2001^{* * * *} \\
(0.2339)\end{array}$ & $\begin{array}{l}0.6577^{* *} \\
(0.3237)\end{array}$ \\
\hline Implement-Complement Coproduction & $\begin{array}{l}-0.2141 \\
(0.2049)\end{array}$ & $\begin{array}{c}-1.0841^{* * * *} \\
(0.2607)\end{array}$ & $\begin{array}{c}-0.8057^{\text {*** }} \\
(0.2804)\end{array}$ \\
\hline School Violence Index (logged) & $\begin{array}{l}-0.5131 \\
(0.8952)\end{array}$ & $\begin{array}{l}-1.2446 \\
(0.8924)\end{array}$ & $\begin{array}{l}-0.7923 \\
(0.9007)\end{array}$ \\
\hline School Violence Index X Design-Core & $\begin{array}{c}2.8573^{* * * *} \\
(0.6498)\end{array}$ & & $\begin{array}{l}1.7069^{* *} \\
(0.7382)\end{array}$ \\
\hline School Violence Index X Implement-Complement & & $\begin{array}{c}2.7908^{* * * *} \\
(0.5851)\end{array}$ & $\begin{array}{l}1.9514^{* * *} \\
(0.6679)\end{array}$ \\
\hline Administrative Personnel per Teacher & $\begin{array}{c}1.2043^{* * *} \\
(0.2902)\end{array}$ & $\begin{array}{c}1.1504^{* * * *} \\
(0.2862)\end{array}$ & $\begin{array}{c}1.1576^{* * *} \\
(0.2875)\end{array}$ \\
\hline Per Capita Parents Involvement Expenses (logged) & $\begin{array}{c}2.0761^{* * * *} \\
(0.5928)\end{array}$ & $\begin{array}{c}1.9840^{* * * *} \\
(0.5822)\end{array}$ & $\begin{array}{c}2.0028^{* * * *} \\
(0.5839)\end{array}$ \\
\hline Per Capita Classroom Instruction Expenses (logged) & $\begin{array}{c}2.4705 \\
(2.6703)\end{array}$ & $\begin{array}{c}2.8444 \\
(2.6197)\end{array}$ & $\begin{array}{c}2.5201 \\
(2.6572)\end{array}$ \\
\hline Female students $(\%)$ & $\begin{array}{c}0.0943 \\
(0.0898)\end{array}$ & $\begin{array}{c}0.0981 \\
(0.0895)\end{array}$ & $\begin{array}{c}0.0942 \\
(0.0892)\end{array}$ \\
\hline Black students (\%) & $\begin{array}{c}0.0735 \\
(0.1018)\end{array}$ & $\begin{array}{c}0.0730 \\
(0.1016)\end{array}$ & $\begin{array}{c}0.0713 \\
(0.1011)\end{array}$ \\
\hline Hispanic students (\%) & $\begin{array}{c}0.1400 \\
(0.0862)\end{array}$ & $\begin{array}{c}0.1489^{*} \\
(0.0867)\end{array}$ & $\begin{array}{c}0.1418^{*} \\
(0.0860)\end{array}$ \\
\hline Class size index & $\begin{array}{c}-0.2582 \\
(0.2455)\end{array}$ & $\begin{array}{c}-0.2604 \\
(0.2454)\end{array}$ & $\begin{array}{c}-0.2679 \\
(0.2459)\end{array}$ \\
\hline Core classes taught by unqualified teachers (\%) & $\begin{array}{c}-0.0413^{\text {*** }} \\
(0.0178)\end{array}$ & $\begin{array}{c}-0.0421^{* * *} \\
(0.0179)\end{array}$ & $\begin{array}{c}-0.0418^{* *} \\
(0.0177)\end{array}$ \\
\hline Turnover rate of all teachers & $\begin{array}{c}-0.0804^{* * * *} \\
(0.0187)\end{array}$ & $\begin{array}{c}-0.0794^{* * *} \\
(0.0187)\end{array}$ & $\begin{array}{c}-0.0799^{* * * *} \\
(0.0187)\end{array}$ \\
\hline Teachers with less than three years of experience (\%) & $\begin{array}{c}-0.0757^{* * * *} \\
(0.0244)\end{array}$ & $\begin{array}{c}-0.0742^{* * * *} \\
(0.0249)\end{array}$ & $\begin{array}{c}-0.0743^{* * * *} \\
(0.0246)\end{array}$ \\
\hline
\end{tabular}




\begin{tabular}{lccc} 
Limited English Proficient students $(\%)$ & 0.0877 & 0.0867 & 0.0816 \\
& $(0.0773)$ & $(0.0777)$ & $(0.0774)$ \\
Students in Poverty $(\%)$ & 0.0433 & 0.0436 & 0.0439 \\
& $(0.0292)$ & $(0.0289)$ & $(0.0291)$ \\
Constant & 16.4466 & 12.9694 & 16.3819 \\
& $(23.8170)$ & $(23.3319)$ & $(23.6976)$ \\
\hline School fixed-effects & Yes & Yes & Yes \\
Year fixed-effects & Yes & Yes & Yes \\
Observations & 2849 & 2849 & 2849 \\
Schools & 1021 & 1021 & 1021 \\
$\mathrm{R}^{2}$ (within) & 0.7499 & 0.7505 & 0.7514 \\
\hline
\end{tabular}

Cluster Robust Standard Errors in parentheses: ${ }^{*} p<0.1,{ }^{* *} p<0.05,{ }^{* * *} p<0.01$ 
FIGURE 1. Marginal Effect of Violence on Average Student Pass Rate as Coproduction Changes
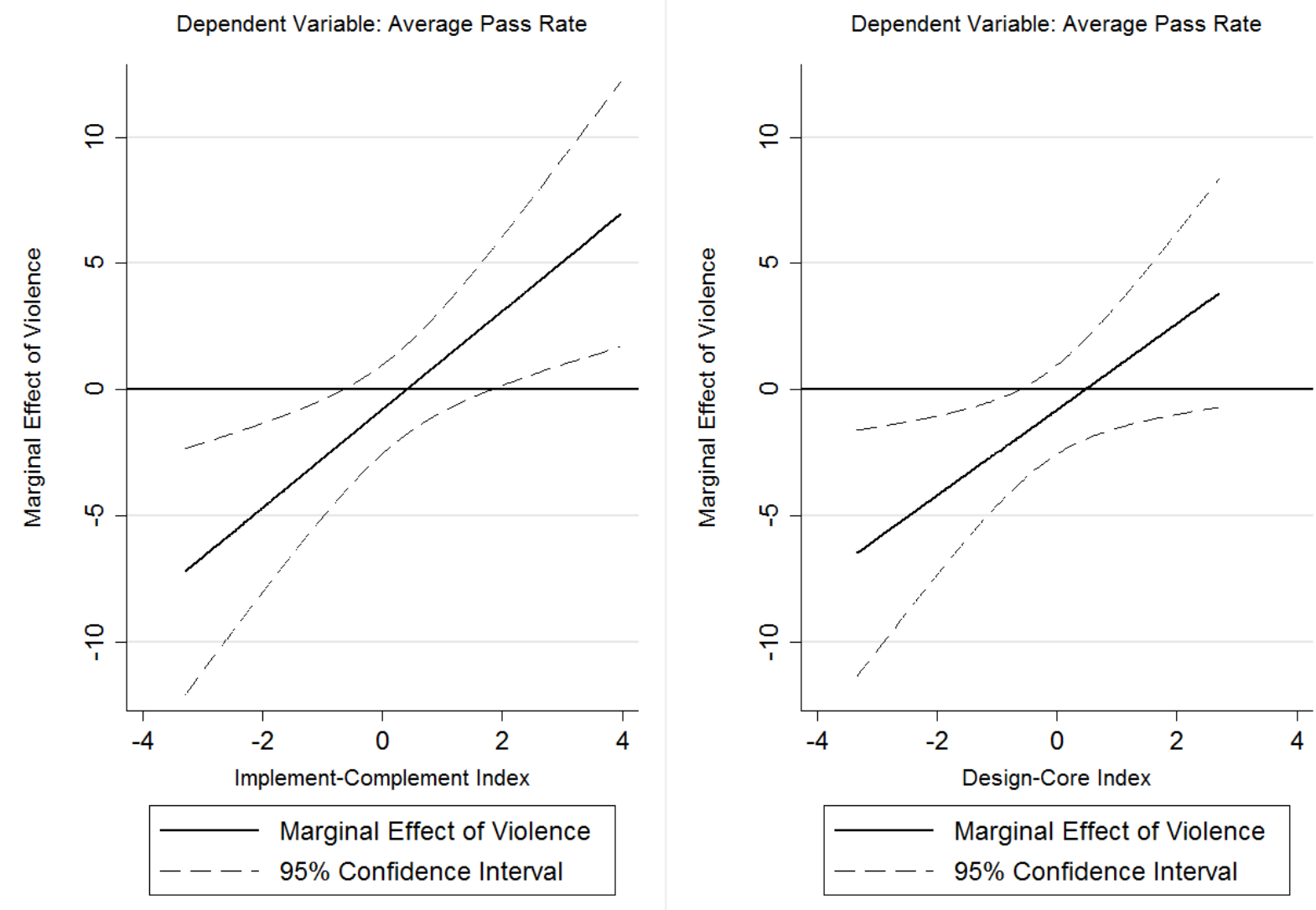